\title{
HIV/AIDS EDUCATION OF HEALTH CARE PROVIDERS
}

\author{
Ljaljevic Agima, Scepanovic Lidija, Mugosa Boban, Catic Sabina
}

Institute of Public Health Montenegro, Podgorica, Montenegro

Primljen/Received 14. 01. 2015. god.

Abstract: Introduction: The aim of this study was to determine perceptions of service providers in the healthcare on their awareness and knowledge about HIV/AIDS, as well as the relationship of the above parameters and the existence of stigma and discrimination against people with HIV/AIDS.

Method: The type of the study was a behavioral cross sectional study. The survey was conducted in 2012 , on a representative sample of health workers in Montenegro. The main survey instrument was specifically designed questionnaire that consisted of six parts, out of which one was related to knowledge about HIV and AIDS. Data were analyzed by methods of inferential statistics.

Results: More than four out of ten respondents have never attended educational workshops on HIV/AIDS. Research has shown that there is a highly significant statistical correlation between estimates of their own knowledge about HIV / AIDS and previous educations. Almost two-thirds of respondents, who attended some type of education in the field of HIV/AIDS, believe to have a satisfactory level of knowledge in the area.

Conclusion: Health care service providers evaluate their knowledge of HIV/AIDS as insufficient.

Key words: HIV/AIDS, service providers in health, knowledge.

\section{INTRODUCTION}

Health workers should protect themselves and their patients in their daily work by using standard non-specific protection measures in order to prevent infections that are transmitted by blood (1). At the same time, it is of particular importance that health workers meet users of health care without stigma and discrimination, as well as without various forms of prejudice. Open approach is of particular importance when speaking of health services for people living with HIV/AIDS. Several qualitative studies, conducted in other countries in the last few years, demonstrated a
Prihvaćen/Accepted 07. 03. 2015. god.

significant degree of stigma and discrimination against people living with HIV among health professionals (2). Studies analyzing causes of stigma and discrimination against people living with HIV/AIDS have not been conducted in Montenegro.

Discrimination against people living with HIV/AIDS is caused primarily by lack of information and knowledge of service providers in the health sector. People living in societies that are facing HIV epidemic often do not have sufficient and accurate information, and perceive HIV as a deadly disease with unknown modes of transmission and unsafe methods of protection, resulting in great fear and sense of personal vulnerability (3). As a result of stigma and discrimination, people living with HIV/AIDS develop uncertainty and distrust in health workers, avoiding available health services that consequently leads to disruption of their health status. The conclusion is that isolation and exclusion of infected people appears to be a natural response to fear. In addition, people living with HIV/AIDS are considered to be members of the population groups that were previously marginalized and stigmatized in society - sex workers, drug addicts and homosexuals, and consequently seen as culprits for their infection. Such perception of people living with HIV leads to external stigma and discrimination, but also to internal, the perceived stigma.

When defining measures for reduction or complete elimination of health workers stigmatization and discrimination against people living with HIV/AIDS, it is necessary to identify essential elements causing this phenomenon. In some cases, the root of stigma is, in fact, the lack of specific knowledge, but very often, regardless of awareness of HIV ways of transmission, most people have irrational fears that come from other sources, Causes of stigma are often deeply rooted in attitudes and moral convictions.

General prerequisites for proper treatment when meeting health needs of users are: adequate education, 
researches focusing on identification of causes of stigma and discrimination, as well as adequate working conditions (4).

The aim of the research was to determine perceptions of service providers in the healthcare, their awareness and knowledge about HIV/AIDS, as well as relationship of the above parameters and the existence of stigma and discrimination against people living with HIV/AIDS.

\section{METHOD}

The survey was conducted as behavioral cross section study.

The survey was conducted in 2012 on a representative sample of health workers in Montenegro. A framework for defining the sample represented official health workers data collected at the Institute of Public Health (8). Each participant has previously had to give consent on voluntary participation in the study.

In planning the sample all health institutions at all levels of health care and all health care workers were included. The sample was stratified so as to give the possibility to representativeness related to the type of institution, level of care, number and gender of employees, as well as their territorial distribution. After stratification, with respect to the foregoing parameters of each identified stratum, were randomly proportion to the size of the strata, identified $10 \%$ of all health care workers involved in the sample. In order to ensure the planned number of patients, due to refusal to participate in the research of a number of respondents, $12 \%$ of all health care workers entered the sample.

The main survey instrument was specifically designed questionnaire that consisted of six parts, out of which one was related to knowledge about HIV/AIDS.

The questionnaire consisted of closed questions that were related to a wide range of knowledge of health workers, from general knowledge of the population that receives information through the media, to very specific knowledge for persons engaged in the diagnosis and treatment of infected by HIV, or suffering from AIDS.

The research was conducted by a research team from the Institute of Public Health and the interviewers were trained prior to conducting research.

Each questionnaire data were entered into previously created database, after which they were treated by the methods of inferential statistics.

For statistical analysis of the data, the statistical software package SPSS has been used. Also, methods of descriptive and inferential statistics, or method of univariate and multivariate statistics for testing the significance of differences and testing connectivity between different variables have been applied.

\section{RESULTS}

Representation of respondents aligned with the structure of donors Facilities in the health system of Montenegro (Figure 1).

Figure 1. The structure of respondees health services providers

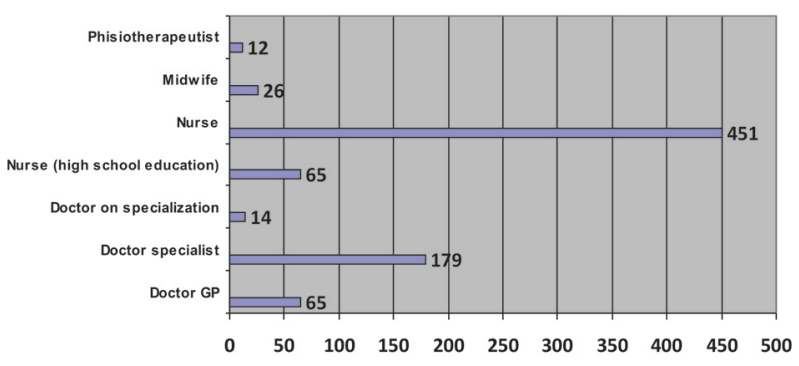

The study included 813 health care providers in Montenegro (which accounts for about $12 \%$ of the total number of employees in this sector) from all institutions at all three levels of health care. Most respondents $(41.5 \%)$ were from Podgorica. More than a quarter of the examined (25.8\%) were men, while among respondents forefront of women, which corresponds to the gender breakdown in health. The age of respondents ranged from 20 to 70 years (retired doctors who work on service contracts), where the average age was 42 years. Length of service examined ranged from one to 43 years, and the average length of service was about 19 years old. The structure of employees, with the participation of more than half $(55.9 \%)$ were dominated by nurses / technicians. As in relation to other categories in the sample represented structure is aligned with the structure of employees.

More than four out of ten respondents (42.6\%) had never attended educational workshops on HIV/AIDS, while $13.5 \%$ attended these workshops in the last year, and $43.9 \%$ in the last five years. Educational workshops were attended by $57.4 \%$ of respondents (Figure 2).

Figure 2. Participation of healthcare workers to educational workshops on HIV/AIDS

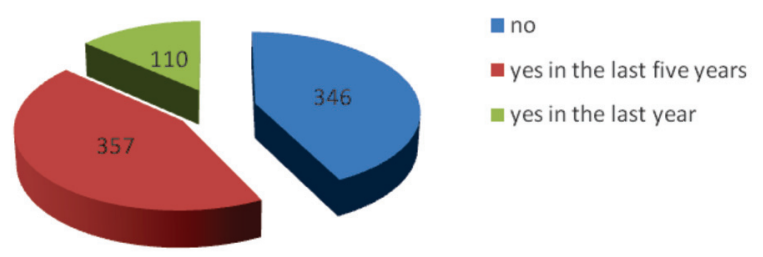

In relation to the field of health care they were engaged in, service providers were mostly physiotherapists, midwives and nurses/technicians who have not had any training in the previous period (Figure 3). It is obvious that there is statistically significant difference in attendance of education in the field of HIV/AIDS 
Figure 3. Attitudes of health workers in relation to needs for education in the field of HIV/AIDS
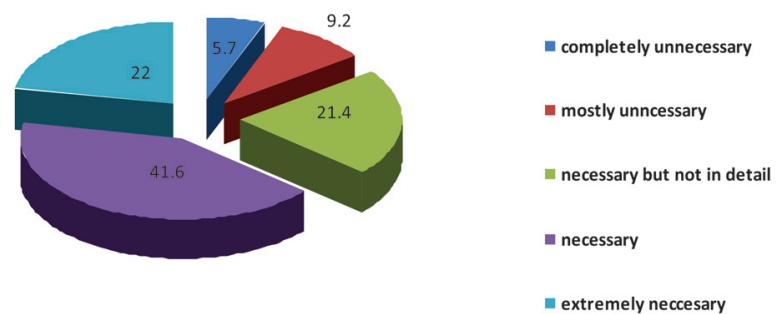

by the field of healthcare of respondents $(\div 2=34.094$; $\mathrm{p}<0.001)$.

Health workers mostly recognize the need for training in the field of HIV/AIDS, while there are differences in the levels of needs for new knowledge in the respective field (Figure 4).

Figure 4. Use of gained knowledge in practice by healthcare service providers

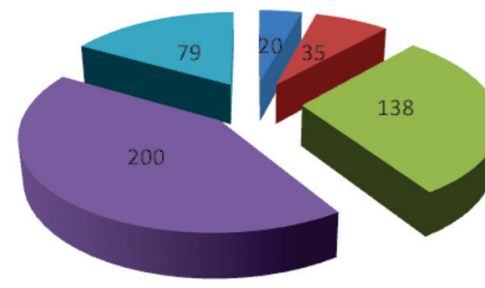

@ almost nothing
very litle
a litle
much
m very much

Research has shown that there is a highly significant correlation between estimates of their own knowledge about HIV/AIDS and past education $(\div 2=105080$; $\mathrm{p}>0.001)$. Among the respondents who indicated that they have not had education on HIV/AIDS, $42.7 \%$ esti- mated to have no knowledge in this field. Among the respondents who indicated that they had some form of education on HIV/AIDS, the highest percentage, at their own opinion, have good knowledge in this area (Table 1).

If we reduce categories of knowledge on HIV/AIDS on two categories: a little and much, we can see that there are statistically significant differences in respondents responses who did and did not attended trainings in the previous period $(\div 2=44.001, \mathrm{p}<0.001)$. Nearly two-thirds of those who attended some types of education in the field of HIV/AIDS are considered to have a satisfactory level of knowledge in the field (Table 2).

\section{DISCUSSION}

Availability of information and increase of knowledge in the field of HIV/AIDS are particularly important for service providers in healthcare, which is why experts say that certain quantum of knowledge is necessary for adequate provision of health services (5). Research has shown that there is a highly significant difference in knowledge of providers of healthcare services in relation to whether they had the opportunity to attend some kind of training in the field of HIV/AIDS or not.

Healthcare service providers estimate that there is an increased risk of HIV transmission from patient to person in their working environment. Such answers indirectly show that health workers do not have enough knowledge about types of exposure that are considered risky. Assessment of the risk of infection that is trans-

Table 1. Correlation between education on HIV / AIDS and knowledge in this field

\begin{tabular}{|l|c|c|c|c|c|c|c|c|}
\hline \multirow{2}{*}{$\begin{array}{c}\text { Assessment } \\
\text { of respondents } \\
\text { knowledge } \\
\text { on HIV / AIDS }\end{array}$} & \multicolumn{3}{|c|}{ No } & \multicolumn{2}{c|}{$\begin{array}{c}\text { Yes in the last five } \\
\text { years }\end{array}$} & \multicolumn{2}{c|}{ Yes in the last year } & \multicolumn{2}{c|}{ Total } \\
\cline { 2 - 9 } & Number & $\%$ & Number & $\%$ & Number & $\%$ & Number & $\%$ \\
\hline Almost nothing & 17 & 68,0 & 6 & 24,0 & 2 & 8,0 & 25 & 100,0 \\
\hline Very little & 105 & 66,9 & 42 & 26,8 & 10 & 6,4 & 157 & 100,0 \\
\hline A little & 153 & 42,7 & 166 & 46,4 & 39 & 10,9 & 358 & 100,0 \\
\hline Much & 61 & 26,5 & 129 & 56,1 & 40 & 17,4 & 230 & 100,0 \\
\hline Very much & 11 & 25,6 & 13 & 30,2 & 19 & 44,2 & 43 & 100,0 \\
\hline Total & 347 & 42,7 & 356 & 43,8 & 110 & 13,5 & 813 & 100,0 \\
\hline
\end{tabular}

Table 2. Correlation estimates of their own knowledge and past education on HIV/AIDS

\begin{tabular}{|l|r|c|c|c|c|c|}
\hline \multirow{2}{*}{$\begin{array}{c}\text { Assessment of respondents } \\
\text { knowledge on HIV/AIDS }\end{array}$} & \multicolumn{6}{|c|}{ Passed education in the field of HIV/AIDS } \\
\cline { 2 - 7 } & Yes & $\%$ & No & $\%$ & Total & $\%$ \\
\hline Little & 273 & 50,7 & 265 & 49,3 & 538 & 100,0 \\
\hline Much & 72 & 26,4 & 201 & 73,6 & 273 & 100,0 \\
\hline Total & 347 & 42,5 & 466 & 57,5 & 813 & 100,0 \\
\hline
\end{tabular}


mitted by blood and opportunities of HIV transmission in the health care setting are directly related to the knowledge of the definition of high-risk procedures and bodily fluids that are considered potentially infectious. Therefore, knowledge of health professionals is extremely important in relation to these aspects of HIV infection (6).

Respondents lined up biological material for transmission of HIV according to the risk assessment for their health, as follows: blood, semen, vaginal secretions, cerebrospinal fluid, saliva, urine, stool and sweat. Similar results were obtained in a research conducted among health workers in primary health care of the Republic of Serbia, in the period from November to December 2008 (7).

In this study, nearly the same number of respondents stated that HIV infection and AIDS are two terms for the same phenomenon, while about $11 \%$ said they did not know the answer to this question. Though this was significantly better than in previous studies (9), there is still plenty of room for further education of providers in healthcare. $\mathrm{Wu}$ and associates found that about one-third of respondents, $27.5 \%$, did not know what abbreviation HIV was and $21.4 \%$ what acronym AIDS meant (8). The data showed that ignorance was present in a significant higher number of respondents, but the research was conducted ten years ago.

The results show that among service providers in health care there was some confusion regarding the mode of HIV transmission, as well as the concepts related to HIV infection. Thus, $22.2 \%$ of respondents believe that HIV can be transmitted by mosquitoes, and $17.1 \%$ do not know whether this statement is true. It is shown that the education of health workers is necessary component in the process of preserving their health, the health of users and overcoming stigma and discrimination. However, it is evident that the prevalence of HIV/AIDS significantly conditions knowledge about this infection, because if the service providers in the health care are more often exposed to work with people living with HIV/AIDS, it provides them more opportunities to learn, to have more experience and to overcome their stigmatizing attitudes. It is quite expected that service providers who provide health care services to persons living with HIV/AIDS have comprehensive and complete information related to this disease than others. Research on knowledge, attitudes and behavior of health workers towards people living with HIV/AIDS in Tanzania (10) showed that no health worker marked mosquito transmits of HIV as a true answer. The same survey in Rwanda (11) showed that only $4.5 \%$ of respondents gave the wrong answer to the question of whether a mosquito can transmit HIV. Also, research on stigma of health workers towards people living with HIV/AIDS in Ukraine showed no misunderstanding with transfer modes (12). Accordingly, it can be noted that in countries with a high prevalence of the disease, knowledge of healthcare providers is fuller and more comprehensive in relation to the specific disease.

Our respondents mostly evaluated their knowledge about HIV/AIDS as insufficient, whereby it should be taken into account that a significant number of them have not had the opportunity to attend training courses in the field (13). Respondents who had attended some kind of training on HIV/AIDS believe that they significantly used gained knowledge in practice. At the same time respondents expressed the need for additional training in various aspects related to HIV/AIDS, which, in accordance with the above, is needed for their daily activities.

\section{CONCLUSIONS}

Healthcare service providers asses their knowledge in the field of HIV/AIDS as insufficient. Less than $20 \%$ of surveyed could specify all necessary means of protection at work when providing services, when there is a possible contact with the blood of the user. There were even fewer correct answers to questions related to possible routes of transmission of HIV, while there was a difference in relation to the field of healthcare they were engaged in service. More often than every fourth provider of health care did not had the opportunity to attend some type of education on HIV/AIDS, but one third of those who have undergone such training believe to use their knowledge in the respective field in practice. It is shown that knowledge in the field of HIV/AIDS is not complete, and should be improved.

\title{
Sažetak
}

\section{HIV/AIDS EDUKACIJAZDRAVSTVENIH RADNIKA}

\author{
Ljaljević Agima, Šćepanović Lidija, Mugoša Boban, Ćatić Sabina \\ Institut za javno zdravlje Crna Gora, Podgorica, Crna Gora
}

Uvod: Cilj ovog istraživanja bio je utvrditi percepcije zdravstvenih radnika o njihovoj svesti i znanju o
HIV/AIDS-u, kao i odnos navedenih parametara i postojanje stigme i diskriminacije osoba s HIV/AIDS-a. 
Metod: radi se o bihejvioralnoj studiji preseka. Istraživanje je sprovedeno tokom 2012. godine, na reprezentativnom uzorku zdravstvenih radnika u Crnoj Gori. Glavni instrument istraživanja je posebno dizajniran upitnik koji se sastojao od šest delova, od kojih je jedan bio u vezi sa znanjem o HIV-u i AIDS-u. Podaci su analizirani pomoću metode inferencijalne statistike.

Rezultati: Više od četiri od deset ispitanika nikada nisu pohađali edukativne radionice o HIV/AIDS-u. Istra-

\section{REFERENCES}

1. Picerno I, Spataro P, Cannavb G, et al. Evaluation of the AIDS risk perception among healthcare workers in the Hospital University Unit of Messina (Italy). J Prev Med Hyg. 2008; 49(3): 97-100.

2. Centers for Disease Control. Update: human immunodeficiency virus infections in health-care workers exposed to blood of infected patients. Morb Mortal Wkly Rep. 1987; 36(19): 285-9.

3. UNAIDS/WHO. Guidelines for using HIV testing technologies in surveillance. Geneva: WHO/CDS/CSR/EDC/2001. 16.UNAIDS/01.22E. 2001; 1-38.

4. Umeh C, Essien J, Ezedinachi E, Ross MW. Knowledge, beliefs and attitudes about HIV/AIDS related issues, and the sources of knowledge among health care profesionals in southern Nigeria. J R Soc Promot Health. 2008; 128(5): 233-9.

5. Kocić B, Petrović B, Bogdanović D, Jovanović J, Nikić D, Nikolić M. Professional risk, knowledge, attitudes and practice of health care personnel in Serbia with regard to HIV and AIDS. Cent Eur J Public Health. 2008; 16(3): 134-7.

6. U.S. Public Health Service. Updated U.S. Public Health Service Guidelines for the Management of Occupational Exposures to HBV, HCV, and HIV and Recommendations for Postexposure Prophy-laxis. MMWR Recomm Rep. 2001; 50(RR-11): $1-52$.

\section{Correspondence to/Autor za korespondenciju}

Prof. dr Agima Ljaljevic

Institute of Public Health

Ljubljanska bb

81000 Podgorica

Montenegro

E-mail: agima.ljaljevic@ijzcg.me

Tel. +382672666795 živanja su pokazala da postoji vrlo značajna statistička povezanost između procena vlastitog znanja o HIV/AIDS-u i prethodnih edukacija. Gotovo dve trećine ispitanika, koji su imali neki tip edukacija o HIV/AIDS-u, veruju da imaju zadovoljavajući nivo znanja o toj oblasti.

Zaključak: Zdravstveni radnici ocenjuju njihovo znaje o HIV/AIDS-u kao nedovoljno.

Ključne reči: HIV/AIDS, zdravstveni radnici, edukacija.

7. Mihajlović I, Kocić B, Cagulović T. Procena znanja zdravstvenih radnika primarne zdravstvene zaštite u opštini Ražanj u vezi sa HIV infekcijom. Acta Medica Medianae. 2009; 48(4): 32-9.

8. Wu Z, Detels R, Ji G, et al. Diffusion of HIV/AIDS knowledge, positive attitudes, and behaviors through training of health professionals in China. AIDS Educ Prev. 2002; 14 (5): 379-90.

9. US Agency for International Development (USAID) Health Policy Initiative, Task Order 1. Stigmatization and Discrimination of HIVpositive People by Providers of General Medical Services in Ukraine. Washington DC: Futures Group, Health Policy Initiative, Task Order 1; 2007.

10. Kitaura H, Adachi N, Kobayashi K, Yamada T. Knowledge and attitudes of Japanese dental health care workers towards HIV-related disease. J Dent.1997; 25(3-4): 279-83.

11. Uebel KE, Nash J, Avalos A. Caring for the caregivers: models of HIV/AIDS care and treatment provision for health care workers in Southern Africa. J Infect Dis. 2007; 196(Suppl 3): $500-4$.

12. Sadob AE, Fawole AO, Sadoh WE, Oladimeji AO, Sotiloye OS. Attitude of health-care workers to HIV/AIDS. Afr J Reprod Health. 2006; 10(1): 39-46.

13. Wilson WO. Infection control issue: understanding and addressing the prevalence of unsafe injection practices in healthcare. AANA J. 2008; 76(4): 251-3. 